\title{
THE NARRATIVE MODEL OF CONSTITUTIONAL IMPLICATIONS: A DEFENCE OF ROACH V ELECTORAL COMMISSIONER
}

\author{
JONATHAN CROWE*
}

The role of implications in Australian constitutional law has long been debated. Jeffrey Goldsworthy has argued in a series of influential publications that legitimate constitutional implications must be derived in some way from authorial intentions. I call this the intentionalist model of constitutional implications. The intentionalist model has yielded a sceptical response to several recent High Court decisions, including the ruling in Roach v Electoral Commissioner that the Constitution enshrines an implied conditional guarantee of universal franchise. This article outlines an alternative way of thinking about constitutional implications, which I call the narrative model. I argue that at least some constitutional implications are best understood as arising from historically extended narratives about the relationship of the constitutional text to wider social practices and institutions. The article begins by discussing the limitations of the intentionalist model. It then considers the role of descriptive and normative implications in both factual and fictional narratives, before applying this analysis to the Australian Constitution. I argue that the narrative model offers a plausible basis for the High Court's reasoning in Roach v Electoral Commissioner.

\section{INTRODUCTION}

Constitutional implications have been controversial in Australia at least since Justice Isaacs railed against them in Amalgamated Society of Engineers $v$ Adelaide Steamship Co Ltd. ${ }^{1}$ The controversy has been sustained by the role of implications in pivotal High Court decisions such as Australian Communist Party $v$ Commonwealth and Melbourne Corporation $v$ Commonwealth. ${ }^{2}$ It arguably

* $\quad$ Professor of Law, Bond University. Earlier versions of this article were presented to audiences at the University of Oxford, the University of Edinburgh, Queen Mary University of London and Griffith University, as well as the annual meeting of the Australasian Society of Legal Philosophy. I am grateful to all who participated in the discussions. Thanks also to the anonymous reviewers for their thoughtful and constructive comments.

1 (1920) 28 CLR 129, 141-2 (Knox CJ, Isaacs, Rich and Starke JJ) ('Engineers' Case').

2 Australian Communist Party v Commonwealth (1951) 83 CLR 1, 192-3 (Dixon J) ('Communist Party Case'); Melbourne Corporation v Commonwealth (1947) 74 CLR 31 ('Melbourne Corporation'). 
reached a high point in the 1990s with the High Court's reliance on an implied freedom of political communication in Nationwide News Pty Ltd v Wills and Australian Capital Television Pty Ltd v Commonwealth. ${ }^{3}$ However, the discussion has hardly abated in recent times. Renewed controversy has greeted the High Court's use of implications as the basis for the doctrine of institutional integrity of state courts established in Kable v Director of Public Prosecutions and the conditional guarantee of universal franchise upheld in Roach $v$ Electoral Commissioner and Rowe v Electoral Commissioner. ${ }^{4}$

What, then, is the proper role of implications in Australian constitutional law? The works of Jeffrey Goldsworthy represent one of the most influential and consistent voices on this issue. Goldsworthy has argued over many years that legitimate constitutional implications must be derived in some way from the intentions of the framers of the Constitution. ${ }^{5}$ I will call this the intentionalist model of constitutional implications. The High Court has encouraged a broadly intentionalist analysis of constitutional implications by the way it has framed some of its more contested decisions. For example, the High Court unanimously held in Lange $v$ Australian Broadcasting Corporation that the implied freedom of political communication was derived from the 'text and structure' of the Constitution most notably, from the term 'directly chosen by the people' in sections 7 and $24 .{ }^{6}$ The same words were later cited in Roach as the basis for the constitutional guarantee of universal franchise. ${ }^{7}$ It has now become commonplace for judges and academics to begin the exercise of constitutional interpretation by referring to the primacy of text and structure. ${ }^{8}$

Nationwide News Pty Ltd v Wills (1992) 177 CLR 1 ('Nationwide News'); Australian Capital Television Pty Ltd v Commonwealth (1992) 177 CLR 106 ('Australian Capital Television').

$4 \quad$ Kable v Director of Public Prosecutions (1996) 189 CLR 51; Roach v Electoral Commissioner (2007) 233 CLR 162 ('Roach'); Rowe v Electoral Commissioner (2010) 243 CLR 1 ('Rowe'). Cf Roach (2007) 233 CLR 162, 218-220 [157]-[162] (Hayne J), 224 [179] (Heydon J); Rowe (2010) 243 CLR 1, 67-72 [194]-[205], 75-6 [219]-[221] (Hayne J), 97-100 [292]-[304] (Heydon J).

5 See, eg, Jeffrey Goldsworthy, 'Implications in Language, Law and the Constitution' in Geoffrey Lindell (ed), Future Directions in Australian Constitutional Law: Essays in Honour of Professor Leslie Zines (Federation Press, 1994) 150; Jeffrey Goldsworthy, 'Originalism in Constitutional Interpretation' (1997) 25 Federal Law Review 1; Jeffrey Goldsworthy, 'Constitutional Implications and Freedom of Political Speech: A Reply to Stephen Donaghue' (1997) 23 Monash University Law Review 362; Jeffrey Goldsworthy, 'Constitutional Interpretation: Originalism' (2009) 4 Philosophy Compass 682; Jeffrey Goldsworthy, 'Original Meanings and Contemporary Understandings in Constitutional Interpretation' in H P Lee and Peter Gerangelos (eds), Constitutional Advancement in a Frozen Continent: Essays in Honour of George Winterton (Federation Press, 2009) 245; Jeffrey Goldsworthy, 'The Case for Originalism' in Grant Huscroft and Bradley W Miller (eds), The Challenge of Originalism: Theories of Constitutional Interpretation (Cambridge University Press, 2011) 42; Jeffrey Goldsworthy, 'Kable, Kirk and Judicial Statesmanship' (2014) 40 Monash University Law Review 75; Richard Ekins and Jeffrey Goldsworthy, 'The Reality and Indispensability of Legislative Intentions' (2014) 36 Sydney Law Review 39; Jeffrey Goldsworthy, 'Functions, Purposes and Values in Constitutional Interpretation' in Rosalind Dixon (ed), Australian Constitutional Values (Hart Publishing, 2018) 43.

6 (1997) 189 CLR 520, 557, 559-62, 566-7 (The Court) ('Lange').

7 (2007) 233 CLR 162, 173-4 [6] (Gleeson CJ), 187-8 [48]-[49] (Gummow, Kirby and Crennan JJ), 218 [155] (Hayne J).

8 For critical discussion, see Adrienne Stone, 'The Limits of Constitutional Text and Structure: Standards of Review and the Freedom of Political Communication' (1999) 23 Melbourne University Law Review 
The intentionalist model, however, often seems to provide an unsatisfactory basis for the High Court's reasoning in implied rights cases. It is doubtful, to say the least, that the constitutional drafters intended later interpreters to infer a constitutionally protected right to freedom of political communication from the wording of sections 7 and 24. This point was made by Dawson $\mathrm{J}$ in his dissenting judgment in Australian Capital Television and has been reiterated by academic critics of the free speech cases. ${ }^{9}$ A similar criticism of the majority's implication of a constitutionally protected universal franchise can be found in the dissenting judgments of Hayne and Heydon $\mathrm{JJ}$ in both Roach and Rowe. ${ }^{10}$ A number of prominent constitutional scholars, including Goldsworthy, have also criticised these cases for straying too far from the intentions of the framers (or, more broadly, being insufficiently grounded in the meaning and context of the Constitution at the time of enactment). ${ }^{11}$

The present article outlines an alternative way of thinking about constitutional implications, which I call the narrative model. ${ }^{12} \mathrm{I}$ argue that at least some constitutional implications are best understood as arising from historically extended narratives about the relationship of the constitutional text to wider social practices and institutions, rather than from the intentions of the constitutional framers. The article begins by discussing the theoretical underpinnings and explanatory limitations of the intentionalist model. It then considers the role of descriptive and normative implications in both factual and fictional narratives, before applying this analysis to the Australian Constitution. I argue that (a) both factual and fictional narratives necessarily make reference to a factual context (including normative and social facts) beyond the text itself; and (b) these external facts are impliedly incorporated into the narrative where they are salient to the task of interpretation. I suggest that applying a similar analysis to constitutions allows us to make sense of a range of established constitutional implications. The article

668; Adrienne Stone, 'The Limits of Constitutional Text and Structure Revisited' (2005) 28 University of New South Wales Law Journal 842.

9 (1992) 177 CLR 106, 182-6. See, eg, Goldsworthy, 'Implications in Language, Law and the Constitution', above n 5, 178-82; Goldsworthy, 'Constitutional Implications and Freedom of Political Speech', above n 5, 371-4; Nicholas Aroney, 'A Seductive Plausibility: Freedom of Speech in the Constitution' (1995) 18 University of Queensland Law Journal 249, 253; Nicholas Aroney, 'The Implied Rights Revolution - Balancing Means and Ends?' in H P Lee and Peter Gerangelos (eds), Constitutional Advancement in a Frozen Continent: Essays in Honour of George Winterton (Federation Press, 2009) $173,183-4$.

10 Roach (2007) 233 CLR 162, 218-20 [157]-[162] (Hayne J), 224 [179] (Heydon J); Rowe (2010) 243 CLR 1, 67-72 [194]-[205], 75-6 [219]-[221] (Hayne J), 97-100 [292]-[304] (Heydon J).

11 See, eg, James Allan, 'The Three "Rs" of Recent Australian Judicial Activism: Roach, Rowe and (No)'riginalism' (2012) 36 Melbourne University Law Review 743; Nicholas Aroney, 'Towards the "Best Explanation" of the Constitution: Text, Structure, History and Principle in Roach v Electoral Commissioner' (2011) 30 University of Queensland Law Journal 145; Anne Twomey, 'Rowe v Electoral Commissioner - Evolution or Creationism?' (2012) 31 University of Queensland Law Journal 181; Goldsworthy, 'Original Meanings and Contemporary Understandings', above n 5, 267-8.

12 I build here on my earlier work on the role of context in constitutional interpretation. See especially Jonathan Crowe, 'The Role of Contextual Meaning in Judicial Interpretation' (2013) 41 Federal Law Review 417; Jonathan Crowe, 'Functions, Context and Constitutional Values' in Rosalind Dixon (ed), Australian Constitutional Values (Hart Publishing, 2018) 61. 
concludes by showing that the narrative model of constitutional implications offers a plausible explanation for the reasoning of the majority judges in Roach.

The narrative model, I suggest, honours the difficulty of constitutional interpretation, while illuminating the way in which judges draw upon historical materials to determine the meaning of the constitutional text. The intentionalist model is sometimes claimed by its defenders to strike an optimal balance between flexibility and stability by grounding the meaning of the Constitution in the original intentions of its framers. This, however, is not the only way that the constitutional text can hold a stable and determinate meaning. The intentionalist model can seem deceptively simple (although the task of identifying and applying the intentions of the framers encounters a range of practical difficulties). ${ }^{13}$ The challenge facing the judiciary, however, is not merely one of identifying the Constitution's meaning in some abstract or theoretical sense. Rather, it involves using the Constitution to regulate the structure of contemporary Australian society. This enterprise, in turn, involves placing the Constitution in a wider legal and social context, and considering its interaction with other institutions and norms. My aim in this article is to show how this task, complex though it may be, nonetheless affords determinate answers that judges can identify through their reasoning. Roach provides an example of how this reasoning process may be carried out.

\section{THE INTENTIONALIST MODEL}

Goldsworthy's writings represent the most detailed and systematic attempt to provide a theoretical basis for the guiding role of authorial intentions in Australian constitutional interpretation. Goldsworthy argues that the High Court's approach to constitutional interpretation is best described as a form of moderate originalism. ${ }^{14} \mathrm{He}$ further contends that this approach gains support from philosophical theories of linguistic meaning, particularly the influential theory of Paul Grice. ${ }^{15}$ Grice's account of linguistic meaning holds that " $A$ meant something by $x$ " is (roughly) equivalent to " $A$ intended the utterance of $x$ to produce some effect in an audience by means of the recognition of this intention"". ${ }^{16}$ This is commonly described as an intentionalist view of meaning, since (in the words of

13 For helpful discussion, see Heidi M Hurd, 'Interpretation Without Intentions' in George Pavlakos and Veronica Rodriguez-Blanco (eds), Reasons and Intentions in Law and Practical Agency (Cambridge University Press, 2015) 52.

14 Goldsworthy, 'Originalism in Constitutional Interpretation', above n 5, 8-16, 19-21; Goldsworthy, 'Original Meanings and Contemporary Understandings', above n 5, 247-53. For a competing view, see Greg Craven, 'Cracks in the Façade of Literalism: Is There an Engineer in the House?' (1992) 18 Melbourne University Law Review 540.

15 See, eg, Goldsworthy, 'Implications in Language, Law and the Constitution', above n 5; Goldsworthy, 'Constitutional Implications and Freedom of Political Speech', above n 5, 362-3; Goldsworthy, 'Originalism in Constitutional Interpretation', above n 5, 39; Goldsworthy, 'Constitutional Interpretation: Originalism', above n 5, 688-9; Goldsworthy, 'The Case for Originalism', above n 5, 46-51; Ekins and Goldsworthy, above n 5, 55-7. 
John Biro) 'its fundamental tenet is that an adequate theory of meaning must assign a quite central role to the intentions of speakers of the language for which it is a theory'.$^{17}$ The emphasis on intention in Grice's theory stems, in turn, from its emphasis on language as a means of communication. On this view, as Biro puts it:

The concept of meaning has its home in the context of the broader notion of communication. Communication is a matter, generally, of a person's conveying of [her or] his thoughts (beliefs, desires, intentions) to others; it depends on the possibility of the two parties somehow converging on the right thought, namely, on the one the speaker intends to convey. It is only if such convergence takes place that understanding - the primary goal of communication - is achieved. ${ }^{18}$

Goldsworthy's reliance on a broadly Gricean approach to linguistic theory can be clearly discerned in his work on constitutional implications, which makes pivotal use of Grice's account of conversational implicatures. ${ }^{19}$ A Gricean conversational implicature is a meaning a speaker intends to convey through an utterance that is neither expressly stated nor logically entailed by the utterance, but which may be inferred from the conventional meaning of the words used, the context of the specific utterance or other items of background information known to or assumed by both the speaker and the audience. ${ }^{20}$ Grice gives the example of a professor whose reference for a student seeking an academic position merely states that the student is fluent in English and regularly attends classes. ${ }^{21}$ The reference does not expressly criticise the student, but the writer clearly means to condemn by faint praise. The professor therefore impliedly asserts that the student is not qualified for the post. This inference about the professor's intentions can be drawn from the context of the utterance.

A Gricean analysis of constitutional implications suggests that implications may legitimately be drawn where the context indicates that the framers' intentions are not captured by the express words of the text. However, this account seems unable to explain at least some aspects of the High Court's jurisprudence. The implied freedom of political communication provides an example. We have seen that the High Court's approach to the implied freedom in Lange emphasised the words 'directly chosen by the people' in sections 7 and 24 of the Constitution.22 The High Court's emphasis on this phrase, as opposed to the underlying doctrine of representative government that some judges emphasised in earlier decisions, ${ }^{23}$ was widely seen as an attempt to legitimise the implied freedom. ${ }^{24}$ However, as noted above, it is not very plausible that the framers of the Constitution, in placing the words 'directly chosen by the people' in sections 7 and 24, intended their

17 John I Biro, 'Intentionalism in the Theory of Meaning' (1979) 62 The Monist 238, 238.

18 Ibid.

19 See, eg, Goldsworthy, 'Implications in Language, Law and the Constitution', above n 5, 179-82;

Goldsworthy, 'Constitutional Implications and Freedom of Political Speech', above n 5, 371-4; Ekins and Goldsworthy, above n 5, 55-7.

20 Grice, above n 16, 30-1.

21 Ibid 33.

22 (1997) 189 CLR 520, 559 (The Court). For discussion, see Stone, 'The Limits of Constitutional Text and Structure', above n 8 .

23 See, eg, Nationwide News (1992) 177 CLR 1, 72-3 (Deane and Toohey JJ); Australian Capital Television (1992) 177 CLR 106, 138-40 (Mason CJ), 211-12 (Gaudron J). Cf Stone, 'The Limits of Constitutional Text and Structure', above n 8. 
audience to infer a constitutionally protected freedom of political communication. A number of authors - including Goldsworthy - have made this point in criticising the implied freedom. ${ }^{25}$

Similar observations can be made about more recent High Court decisions. The High Court in Roach ruled by majority that a blanket ban on prisoners serving custodial sentences voting in Commonwealth elections was an unconstitutional restriction on the franchise. This decision has been criticised by some commentators for its lack of foundation in either the constitutional text or electoral practices at the time of Federation. ${ }^{26}$ These criticisms are understandable if one adopts a broadly intentionalist approach to constitutional implications, since it is hard to see how the outcome in Roach could be justified by reference to the framers' intentions. It seems more likely that, if asked, the framers would have said their intention was to leave the scope of the franchise at the discretion of the Parliament. Similarly, the High Court's decision in Kirk v Industrial Court of New South Wales that the power to correct jurisdictional errors by lower courts or tribunals is a defining characteristic of 'the Supreme Court of a State' within the meaning of section 73 of the Constitution has been criticised for lacking a basis in constitutional practice at the time of enactment. ${ }^{27}$ This, in turn, undermines the High Court's interpretation of section 73 if we assume that any implications drawn from its terms must be based on the intentions and knowledge of the provision's framers.

What other resources might an intentionalist theory of meaning offer for understanding the High Court's approach in these cases? Conversational implicatures, as noted above, can serve as assertions (or other kinds of speech acts, such as commands or permissions). Presuppositions, on the other hand, are often defined by distinguishing them from assertions. A presupposition is an assumption that can be inferred from either the speaker's assertion or denial of a particular proposition..$^{28}$ A person who says she regrets voting for Barack Obama given his record on drone strikes, for example, invokes the presupposition that she voted for Obama. The same presupposition would arise if the person stated she did not regret

25 See, eg, Goldsworthy, 'Implications in Language, Law and the Constitution', above n 5, 179-82;

Goldsworthy, 'Constitutional Implications and Freedom of Political Speech', above n 5, 371-4; Aroney, 'A Seductive Plausibility', above n 14, 253; Aroney, 'The Implied Rights Revolution', above n 9, $183-4$. See also Australian Capital Television (1992) 177 CLR 106, 182-6 (Dawson J).

26 See, eg, Allan, above n 11, 753; Aroney, 'Towards the "Best Explanation" of the Constitution', above n 11; Twomey, above n 11, 183-6.

27 (2010) 239 CLR 531, 580-1 (French CJ, Gummow, Hayne, Crennan, Kiefel and Bell JJ) ('Kirk'). See, eg, Goldsworthy, 'Kable, Kirk and Judicial Statesmanship', above n 5, 93-9; Oscar I Roos, 'Accepted Doctrine at the Time of Federation and Kirk v Industrial Court of New South Wales' (2013) 35 Sydney Law Review 781; Luke Beck, 'What is a "Supreme Court of a State"?' (2012) 34 Sydney Law Review 295, 302-3. Contra Constance Youngwon Lee, 'Constitutional Silences and Institutional Integrity' in Rebecca Ananian-Welsh and Jonathan Crowe (eds), Judicial Independence in Australia - Contemporary Challenges, Future Directions (Federation Press, 2016). For a discussion of Kirk v Industrial Court of New South Wales, see Suri Ratnapala and Jonathan Crowe, 'Broadening the Reach of Chapter III: The Institutional Integrity of State Courts and the Constitutional Limits of State Legislative Power' (2012) 36 Melbourne University Law Review 175, 189-94.

28 Robert C Stalnaker, Context and Content (Oxford University Press, 1999) 47. See generally Grice, above n 16, 269-82. 
voting for Obama. Statutory interpretation makes common use of presuppositions: for example, it is generally presupposed that a statute does not apply retrospectively unless clearly intended to do so. This assumption exists regardless of the specific content of the legislation. It is therefore presupposed by the legislation, rather than implied.

Presuppositions are sometimes suggested as an alternative basis for the High Court's reasoning about constitutional implications. ${ }^{29}$ The words 'directly chosen by the people', it might be said, show that the framers envisaged a system of representative government. A working system of representative government is therefore a presupposition (although not an implication) of sections 7 and 24. This, in turn, requires some level of freedom to debate competing points of view. The Constitution therefore presupposes freedom of political communication. However, the notion of a presupposition, as used in linguistic theory, still gives a prominent role to authorial intentions..$^{30}$ The person who says she regrets voting for Obama, for example, clearly intends the listener to infer that she voted for him. It is doubtful, however, that a robust guarantee of political communication would have formed part of the framers' conception of representative government. Indeed, it seems more plausible that they presupposed the contrary: they would have expected the boundaries of political speech and the franchise to be defined by the legislature. ${ }^{31}$

An alternative view might be that the framers presupposed a system of representative government without a clear or detailed sense of what that might entail. However, this raises the question of how the content of the presupposition is to be determined if not by reference to the understanding of the framers. A shift in focus from implicatures to presuppositions, then, does not straightforwardly support the High Court's jurisprudence in the cases mentioned above. More generally, a focus on authorial intentions at this level looks unpromising as an explanation for the High Court's approach. What, then, lies behind the cases? Is it a matter, as some critics have suggested, of the High Court judges legislating from the bench ${ }^{32}$ This strikes me as too simplistic a view. My aim in this article is to sketch the contours of an alternative way of understanding the High Court's decisions. At the least, I want to suggest that appealing to authorial intentions is not the only way to provide a plausible grounding for constitutional implications.

29 For discussion, see Goldsworthy, 'Implications in Language, Law and the Constitution', above n 5, 150; Jeffrey Goldsworthy, 'Constitutional Implications Revisited' (2011) 30 University of Queensland Law Journal 9, 13-15; Ekins and Goldsworthy, above n 5, 55-7.

30 See generally Goldsworthy, 'Constitutional Implications Revisited', above n 29, 13-15; Ekins and Goldsworthy, above n 5, 55-7.

31 See Aroney, 'A Seductive Plausibility', above n 9, 253, 260-2; Aroney, 'The Implied Rights Revolution', above $n$ 9, 178-84.

32 See, eg, James Allan and Nicholas Aroney, 'An Uncommon Court: How the High Court of Australia Has Undermined Australian Federalism' (2008) 30 Sydney Law Review 245; Allan, above n 11; Goldsworthy, 'Kable, Kirk and Judicial Statesmanship', above n 5. 


\section{FACTUAL NARRATIVES}

'Constitutions work'. ${ }^{33}$ They do things in the world. They stand in relation to the world and thereby change it. It would not be possible for constitutions to change the world unless they were themselves part of the world. Constitutions, then, are not properly understood as collections of words detached from the world around them. Rather, they are inextricably connected with the surrounding social and legal context. Constitutions shape the world and, at the same time, the world shapes constitutions. The process of interpreting a constitution is at least partly a process of understanding the relationship of the constitution to the world. Constitutions make reference to things and events and these things and events are properly understood, not as abstract constructions, but as things and events in the world. The factual context for a constitution is found outside the constitution itself. $^{34}$

Section 51 of the Australian Constitution, for example, refers to entities such as trade, taxation, money, lighthouses, fisheries, weights, corporations and railways. These terms are properly and naturally understood as referring to the examples of those things found in the actual world. The world contains instances of trade and taxation. It contains money and corporations. These actually occurring things are the things to which the Constitution refers. Constitutional interpreters, in working out the meaning of section 51, must look not only at the content of the constitutional text, but also at the nature of the things to which it refers. They must pay attention to the way those things relate to other aspects of the world around them. The meaning of taxation, then, involves looking at the instances of taxation found in Australia and assessing their relationship to other types of things, such as fees for services. ${ }^{35}$ This type of analysis would not be possible without a background context of factual material not found within the confines of the Constitution itself.

The Constitution, in this sense, bears some resemblance to a factual narrative. No factual narrative, no matter how complete and detailed, can create a whole world within itself. It necessarily draws on factual information from the actual world as known to the narrator and the interpreter. It is part of the genre of a factual (as opposed to fictional) narrative that the things and events referred to in the narrative form part of the fabric of the actual world. The interpreter properly understands the information presented in the narrative as standing in an actual relation to the world around her (understood as encompassing historical facts about the time when the events in the narrative occurred). An interpreter who is familiar with the context can, in this way, accurately understand a fairly sparse factual narrative. It is not necessary, given a shared set of understandings, for the narrator to fill in all the details.

A factual narrative calls upon the interpreter to fill in the gaps in the story by drawing on material from the actual world. Both the narrator and the interpreter

33 M J Detmold, 'Australian Law: Federal Movement' (1991) 13 Sydney Law Review 31, 31.

34 Crowe, 'The Role of Contextual Meaning', above n 12, 422-4.

35 See, eg, Air Caledonie International v Commonwealth (1988) 165 CLR 462; Airservices Australia v Canadian Airlines International Ltd (1999) 202 CLR 133. 
tacitly understand that the story involves actual facts and the surrounding context for the story is also factual. This understanding is partly captured by what Grice calls the maxim of quality: successful communication typically depends upon the speaker striving to be truthful. ${ }^{36}$ It is also part of the principle of charity proposed by Donald Davidson that interpreters generally credit speakers with holding true beliefs about the world. ${ }^{37}$ The understanding between speaker and interpreter in the case of a factual narrative is not just that the information conveyed in the narrative is truthful, but that the information is to be interpreted against the background of facts about the actual world. Factual narratives therefore rely upon a presupposition of the following kind to supply significant parts of their meaning:

1. The (factual) world is the way it is and not some other way.

The implicit reliance of a factual narrative on facts about the actual world enables a narrator to communicate successfully while complying with what Grice calls the maxim of quantity: supply the necessary amount of information, but no more. ${ }^{38} \mathrm{~A}$ narrator who tried to stipulate all the background facts necessary to make sense of her story would violate that maxim just as much as someone who leaves crucial information unstated. Some of the factual information necessary to understand a story is necessarily presumed. This enables the narrator and interpreter to rely upon factual background that is never directly mentioned or brought to mind, unless it becomes salient to a particular interpretive issue between them. It also enables a narrator to rely upon facts of which she may be unaware to facilitate understanding of her story by interpreters. Consider, for example, the following narrative:

The Mystery of Water: A child takes her favourite cup out to the edge of the balcony during a rainstorm. She carefully extends her arm out over the edge of the balcony and collects a full cup of rainwater. She gently places her cup of water on the balcony table for safekeeping. Later that day, the sun comes out and the day becomes hot. That night, when the child comes outside to collect her precious water, the cup is empty.

The child may not understand what happened. She may ask her mother plaintively what happened to her water. The mother in this scenario will understand the story better than her child: she will know, as the child does not, that water evaporates when it is hot. It is true in the story, even as told from the child's point of view, that the water evaporated. It is equally true that the water evaporated because the heat of the sun agitated the hydrogen and oxygen atoms in the water, even though neither the child nor the mother may be aware of that fact. A story about water is a story about $\mathrm{H}_{2} \mathrm{O}$, even if the narrator and interpreter know no chemistry. This is so in virtue of the fact that water is $\mathrm{H}_{2} \mathrm{O} .{ }^{39}$ The identity of water

36 Grice, above n 16, 27.

37 Donald Davidson, 'Radical Interpretation' (1973) 27 Dialectica 313, 322.

38 Grice, above n 16, 26.

39 See Hilary Putnam, 'The Meaning of "Meaning"' (1975) 7 Minnesota Studies in the Philosophy of Science 131, 139-142. For discussion of Putnam's semantic realist account of linguistic meaning and its implications for constitutional interpretation, see Patrick Emerton, 'Political Freedoms and Entitlements in the Australian Constitution - An Example of Referential Intentions Yielding Unexpected Legal Consequences' (2010) 38 Federal Law Review 169; Michael Stokes, 'Meaning, Theory and the Interpretation of Constitutional Grants of Power' (2013) 39 Monash University Law Review 319, 337-44. 
with $\mathrm{H}_{2} \mathrm{O}$ is implied in the story, even if the narrator and her audience are unaware of it. This is because the story takes place in the actual world: a world in which water is $\mathrm{H}_{2} \mathrm{O}$.

The narrator and the audience of a factual narrative are likely to be unaware of many salient facts about the world in which the story occurs, but they nonetheless presuppose them. The facts relied on to interpret a narrative may therefore change as our knowledge changes. Imagine, for example, the following tale related by an ancient mariner:

Journey to the End of the World: The mariner tells how he was once on a long ocean voyage when the ship was blown adrift in stormy seas. The ship drifted for many days and nights without bearings. At last, the storm lifted and the crew found themselves in calm but uncharted waters. They sailed on towards the horizon, noticing that it strangely seemed to loom closer and closer. At first, they thought they were approaching land, but as they sailed on it seemed there was nothing beyond the horizon but a shapeless void. The crew realised that they had journeyed to the end of the world. They quickly turned the ship around to avoid falling off the edge and sailed in the opposite direction, giving thanks for their good fortune in avoiding disaster.

It is possible that the mariner telling this story is simply spinning a tall tale. The narrative would then be a fictional one. However, it is equally possible that the events actually happened and the mariner fully believes that he almost fell off the edge of the world. A contemporary of the mariner who hears the story may also believe that this is what occurred. The mariner and his contemporary will be operating on a common assumption that the world is flat and it is possible to travel to its end. Modern interpreters, though, will view the story differently. We now know that the world is roughly spherical and you cannot fall off it, so we will interpret the story with this in mind. We might still assume that the mariner is telling the truth as he sees it. However, we will seek alternative explanations for the phenomena he describes.

Suppose that we credit the mariner with telling the truth as he sees it. The mariner and his audience - whether ancient or modern - then view the story as a factual narrative and operate on the common assumption that the world is the way it is and not some other way. A contemporary of the mariner will accordingly interpret the tale by using the assumption that the world is flat. She will share the traveller's relief at disaster averted. A modern interpreter, on the other hand, will share the assumption that the world is as it is, but this will lead her to interpret the narrative differently. She will seek to make sense of the narrative by using the factual assumption that the world is not flat. She will, in doing so, be interpreting the narrative consistently with the traveller's presumed intention to convey a factual story.

This example shows the role of interpretation in making sense of what is implied by a factual narrative. Every narrative takes place against certain background assumptions that are necessary to make sense of it. These assumptions are unlikely to be fully explicit and may, in some cases, not be fully known to the narrator or her audience. The content of the assumptions may change as our knowledge of the world changes. The narrator does not necessarily intend to convey this specific information, since she may not bring it to mind or perhaps 
even know about it. We would not say, for example, that the mariner intends to convey to a contemporary interpreter that the world is not flat. In a broader sense, however, an interpreter who draws on current factual knowledge to understand the content of a historical narrative is nonetheless interpreting it consistently with the more general intention of the narrator to present a factual account of the events concerned. She is faithful to the assumption that the world is as it is and not some other way.

\section{FICTIONAL NARRATIVES}

We have seen that factual narratives rely on the background assumption that the world is as it is. This means that there may be facts implied by the narrative of which both the speaker and her audience are unaware. It also means that the factual background to a story may change as the audience's understanding of the world changes. This may result in the narrative bearing quite different meanings at different points in time. These results follow because a factual narrative takes the world as given. A fictional narrative, on the other hand, presents a story about a world that is either subtly or fundamentally different from the actual world. That is what makes it fictional.

I will return later to the question of whether a constitution is more like a factual or a fictional narrative. (I will suggest that it has elements of both.) Let us focus for present purposes on the difference between the two genres with respect to factual implications. A fictional narrative obviously does not imply that the world is exactly as it is. It seeks to modify the world in certain ways. However, it is equally obvious that a fictional narrative does not present a world that is completely different from the actual world. The very possibility of communication requires a shared language between a narrator and her interpreters. This, in turn, requires at least a basic array of shared concepts. It is therefore impossible for the author of a fictional narrative to create a new world out of nothing. She must start with certain elements of the world as it exists and use these to create a fictional universe.

The classic philosophical discussion of this point comes from the work of David Lewis. ${ }^{40}$ Lewis points out that fictional narratives are read against 'a background of well-known fact'. ${ }^{41}$ The content of the fictional work therefore does not derive purely from the explicit statements contained in the work itself. Rather, it comes from a combination of 'the explicit content' of the story and 'the factual background' presupposed by readers..$^{42}$ The Sherlock Holmes stories by Sir Arthur Conan Doyle, ${ }^{43}$ to use Lewis's example, say that Holmes lives at 221B Baker Street. The stories never explicitly state that Holmes lives nearer to Paddington Station than Waterloo Station, but a map of London (as it exists in the world external to the story) shows that Holmes's address in Baker Street is nearer to

40 David Lewis, 'Truth in Fiction' (1978) 15 American Philosophical Quarterly 37.

41 Ibid 41.

42 Ibid.

43 Sir Arthur Conan Doyle, Sherlock Holmes: The Complete Novels and Stories (Bantam, 1986). 
Paddington than Waterloo. Lewis concludes it is true in the Holmes stories that Holmes lives nearer to Paddington than Waterloo, even though the stories never explicitly confirm this. ${ }^{44}$

There are also, as Lewis points out, a vast array of other background facts that seem to be implicit in the Sherlock Holmes stories, even though they are never directly discussed in the text:

I claim that it is true, though not explicit, in the stories that Holmes does not have a third nostril; that he never had a case in which the murderer turned out to be a purple gnome; that he solved his cases without the aid of divine revelation; that he never visited the moons of Saturn; and that he wears underpants. ${ }^{45}$

There could, of course, be stories - even stories about Holmes - where these assertions are false. However, the genre of the canonical Holmes stories encourages the reader to make certain assumptions about the structural features of the universe that Holmes inhabits. Indeed, the stories rely upon at least some of these assumptions to fill in the factual backdrop and enable readers to make sense of the narrative. Any Holmes story that does not explicitly depart from these assumptions is properly assumed by readers not to do so. It is therefore true that in the stories Holmes does not have a third nostril. Even though the stories do not address this detail of Holmes's physiognomy, the truth value of the proposition is not indeterminate. It is part of the factual backdrop supplied for the stories by the actual world.

Kendall Walton describes the view of truth in fiction defended by Lewis as the Reality Principle. 'The basic strategy' behind the Reality Principle, according to Walton, 'is that of making fictional worlds as much like the real one as the core of primary fictional truths permits' ${ }^{46}$ Fiction, of course, characteristically features departures from the actual world. These departures may be relatively modest, as in the Holmes stories, or more fundamental, as in fantasy novels. The Twilight novels, for example, describe a world where vampires and werewolves live alongside unsuspecting humans. ${ }^{47}$ Bella Swan falls in love with Edward Cullen, only to discover that he is a vampire; her best friend, Jacob Black, turns out to be a werewolf. (Who knew?) Even the Twilight stories, however, derive their meaning from a diverse array of background facts drawn from the actual world.

44 Lewis, above $\mathrm{n} 40,41$.

45 Ibid.

46 Kendall L Walton, Mimesis as Make-Believe: On the Foundations of the Representational Arts (Harvard University Press, 1990) 144-5. Walton argues against the Reality Principle as a general theory of truth in fiction, because it gives creators too little control over their fictional world and interpreters too little access to it: at 153 . However, he acknowledges that the principle is generally a sound guide to interpretive practice: at 157 . Furthermore, he views the Reality Principle as particularly salient in relation to fictional truths about serious normative judgments: at 154-5. Walton's arguments therefore bolster the potential salience of Lewis's view for constitutional implications. Constitutions, unlike fictional narratives, are both grounded in and causally related to the actual world; they do not claim to give their creators control over the boundaries of the factual universe. Furthermore, the meaning of a constitution often depends upon its interaction with other serious legal and social norms; in this respect, as Walton notes, the Reality Principle is particularly salient. I will return to these issues at greater length below.

47 Stephenie Meyer, Twilight (Little, Brown and Company, 2005); Stephenie Meyer, New Moon (Little, Brown and Company, 2006); Stephenie Meyer, Eclipse (Little, Brown and Company, 2007); Stephenie Meyer, Breaking Dawn (Little, Brown and Company, 2008). 
Bella and Edward live in Forks, Washington, an actual place with a rainy climate suited to vampires. They become infatuated and fall in love like actual teenagers with the added challenges presented by Edward's immortality, thirst for blood and so on. These resonances with the actual world help fill in the story and give it meaning for readers.

A fantasy story, as the Twilight example shows, can feature people and events quite alien to the actual world. It might introduce physical deformities, strange creatures and trips to outer space. Holmes might therefore appear in such a novel with a third nostril and travel to the moons of Saturn. He might have a divine revelation that leads him to apprehend a purple gnome, then take off his trousers and shock his companions with his unexpected lack of undergarments. Holmes could be a vampire and Watson a werewolf. The possibilities are literally endless. However, even fantasy novels depend upon factual assumptions that are continuous with the actual universe. The narrative may defeat some of our assumptions, but others will remain in place throughout. No novelist can create a whole universe out of new cloth. Every fictional world, no matter how rich, draws on background material.

Novelists can construct their fictional universes so that they depart from fact in certain ways. However, they are powerless to enact the complete closure of their fictional world. There are always background facts in play. This analysis suggests that fictional narratives rely on an implication of the following kind to supply significant parts of their meaning:

2. The (factual) world is the way it is and not some other way, except as stipulated or implied by the narrative.

The contours of the narrative, on this view, fall to be determined by interpreters by drawing on both the content of the fictional narrative and their knowledge of the actual world. The Holmes universe, then, is the actual universe, except as modified by the narrative. There was, in fact, no dwelling house at 221B Baker Street in the late nineteenth century. ${ }^{48}$ The Holmes stories, however, create a world where there is a dwelling house at that address, without altering the location of the address within London. There are, similarly, no actual vampires and werewolves (so far as we know). The Twilight novels, however, create a universe where such creatures exist, while retaining facts about geography, infatuation, angst and love from the real world. These assumed facts are what give the stories much of their meaning. It would be impossible to make sense of them without this implicit backdrop.

\section{NORMATIVE IMPLICATIONS}

Factual and fictional narratives, then, necessarily rely on a presumed factual backdrop derived at least partly from the world outside the narrative. This backdrop supplies the descriptive context for the story. Narratives also rely on 
assumptions about human values and norms of conduct. These assumptions provide the story's normative context. Consider the story discussed above concerning the ancient mariner. The mariner describes the shock and fear of the crew when they beheld what they took to be the edge of the world. He recounts their mad struggle to turn the ship around and their relief and thanksgiving when they succeed in doing so. We have seen that the interpreter of this narrative understands it against a background of assumed factual information and that this context changes depending on the interpreter's knowledge about the actual world where the story occurs.

It is equally true, however, that the mariner's story is interpreted against a backdrop of normative information that helps shape its meaning. The emotions and actions of the crew in beholding the end of the world make sense to us because we assume that they value their lives and safety. They want to survive the voyage, travel home safely and see their loved ones. They want to live long, full and flourishing lives. The mariner's story would make little sense without this normative backdrop. The kinds of normative assumptions described above concern the values and motivations of the characters in the story. We will often struggle to understand a factual or fictional narrative if we cannot grasp the motivations of the protagonists.

A narrator telling a story will typically not pause to explain that the characters in the narrative value their lives and wish to protect their friends and families. We will generally assume that a character in a story shares these fundamental human motivations, unless the narrative stipulates or implies otherwise. A horror story, for example, may depict a serial killer made chilling by his disregard for human suffering. However, we will not typically assign a character this kind of profile unless the narrative leads us to do so. We will assume that the people in the story are basically like us, in that they share the same fundamental values. It is this normative backdrop that renders the actions and attitudes of the characters intelligible to the audience.

It is for this reason that natural law authors who advance theories of basic human goods view these accounts as capturing the intelligibility conditions of human behaviour. ${ }^{49}$ Basic human values, such as life, health, friendship, play and aesthetic experience, on this view, do not in themselves place deontic restraints on human action. They are, rather, the objectives that render our actions intelligible to other humans. An action that is not directed at one or more of these basic goods is not necessarily morally wrong, but rather incomprehensible or incoherent. We find it hard to make sense of a person's actions when they do not appear to be aimed at any of these values. A theory of the basic goods, then, is precisely an account of the basic normative assumptions we characteristically use to make sense of narratives about human action (whether these narratives are factual or fictional in character).

49 See John Finnis, Natural Law and Natural Rights ( $2^{\text {nd }}$ ed, Oxford University Press, 2011) chs 3-4. For discussion, see Jonathan Crowe, 'Natural Law and Normative Inclinations' (2015) 28 Ratio Juris 52, 57 8; Robert P George, 'Recent Criticism of Natural Law Theory' (1988) 55 University of Chicago Law Review 1371. 
Another kind of normative implication concerns deontic limits on human behaviour. We interpret narratives against a set of background assumptions about the normative status of certain kinds of actions. These normative assumptions help us make sense of the narrative by both casting light on the motivations of the characters and guiding our interpretation of their behaviour. The Cullen family in the Twilight stories, for example, is a vampire coven that chooses not to hunt humans for ethical reasons. Edward struggles with his lust for blood and his capacity to injure Bella with his superhuman strength. These features of the story make sense because we see that Edward and his family share with us some basic deontic assumptions, such as a very weighty norm against killing or injuring innocent people. This normative assumption helps us to understand Edward's internal struggle and motivates us to look critically at those vampires who kill innocent people for their blood. It both aids our understanding of Edward's character and plays a crucial role in giving meaning to the surrounding narrative.

Normative implications operate in factual and fictional narratives in a similar way to the factual implications explored previously. A factual narrative will be assumed to take place in the actual world. We will interpret the protagonists' actions against the backdrop of the basic human values and norms that characterise the world as we know it. There are, of course, some people in the actual world who act unintelligibly or flout basic norms of human conduct, but we will not assume that a person falls into this category unless there is evidence to this effect. We will assume that the people in a narrative recognise weighty norms against taking human life and deliberately inflicting serious suffering. We will react to people who do not appear to share these normative assumptions by critically assessing their actions and seeking some explanation for their amoral conduct. This hermeneutic backdrop guides our interpretations regardless of whether the narrative expressly alludes to it. Factual narratives therefore typically rely upon a normative implication of the following kind to furnish their meanings and guide interpretations:

3. The (normative) world is the way it is and not some other way.

Fictional narratives invoke an assumed normative backdrop in a similar way. However, they may depart from our usual normative assumptions by stipulating or implying this in the narrative. We saw previously that fictional narratives invariably draw on assumed facts about the actual world, but they can alter these facts to create the fictional universe. Fictional narratives similarly rely on normative assumptions to supply their meaning: it is impossible to make sense of the drama, tragedy and comedy in a story without relying on shared knowledge about human values and motivations. They may, however, depart from these assumptions to create a fictional world. Dystopian novels, for example, may depict a fictional universe where society is structured by alien and oppressive norms. The power of such narratives derives precisely from the ways in which they vary the normative structure of the actual world and subvert our expectations about human behaviour (although they may, of course, uncomfortably mirror actual attitudes).

Fictional narratives, then, may depart from the normative structure of the actual world. However, as with factual information, they are powerless to enact the complete closure of their normative universe. A fictional universe that tried to 
construct an entirely alien set of norms out of whole cloth would fail to engage and speak to us. We would be unable to connect with the motivations of the characters that inhabit it. Fictional narratives, then, rely upon the following basic assumption to supply their meaning:

4. The (normative) world is the way it is and not some other way, except as stipulated or implied by the narrative.

\section{THE SOCIAL WORLD}

Factual and fictional narratives take place in a world that either tracks the actual world or modifies it in certain ways. This world, as we have seen, contains both facts and norms. It also contains both physical and social entities. The world in which a narrative occurs is, at least in part, a social world. Social facts can change the world in both its factual and normative dimensions. They do this, in part, by creating new institutions and practices. It will be useful, for our purposes, to distinguish these two ideas. I use the term institution here to refer to the kinds of institutional facts analysed by John Searle. ${ }^{50}$ Institutional facts, for Searle, arise 'when we collectively impose a function on a phenomenon whose physical composition is insufficient to guarantee the performance of the function' ${ }^{51}$ Money, for example, owes its existence to collective acceptance of its function as a medium of economic exchange.

Searle views institutional facts as created by the collective acceptance of constitutive rules of the form ' $\mathrm{X}$ counts as $\mathrm{Y}$ in context $\mathrm{C}$ '. ${ }^{52}$ The institutional facts exist only in virtue of these rules. The rules are manifested by a kind of collective intention towards the relevant phenomena. Searle says this collective intention involves the 'acknowledgement of a new status to which a function is assigned.' 53 The constitutive rules of money, for example, assign to notes and coins a status (money) associated with a function (serving as a medium of exchange). Searle calls this combination a status function..$^{54}$

Institutional facts can change the world without changing its physical composition. Consider the following case:

Tree Bench: A tree falls down in the middle of a village. Workers in the village begin to regularly use the tree as a place to sit while they eat their lunch. They think and speak about the tree as they would a bench placed there for their use. They say things to each other like, 'I'll meet you on the bench at lunchtime'. ${ }^{5}$

50 John R Searle, The Construction of Social Reality (Free Press, 1995); John R Searle, Making the Social World - The Structure of Human Civilization (Oxford University Press, 2010).

51 Searle, The Construction of Social Reality, above n 50, 124.

52 Ibid 28.

53 Ibid 40.

54 Ibid 41.

55 I discuss this case in Jonathan Crowe, 'Law as an Artifact Kind' (2014) 40 Monash University Law Review 737, 740. See also Crowe, 'Functions, Context and Constitutional Values', above n 12, 64-6. Cf Searle, The Construction of Social Reality, above n 50, 39-40. 
It seems plausible that the fallen tree in this example has become a bench. This change occurs without any change in the composition in the bench. The tree becomes a bench by virtue of collective acceptance of a new status function by members of the community. Institutions are pervasive in social life. They can create new facts, as when they give rise to entities such as banks, schools, clubs and ten dollar notes. They can also create new norms by playing a coordination function. Institutions give rise to structured ways of pursuing basic human values. They direct human cooperation into certain channels and therefore give people a reason to select those channels when they wish to collaborate with others to promote some common goal. ${ }^{56}$ People who need a common medium of exchange to trade goods or services for mutual benefit have reason to use recognised currency for this purpose. They have this reason partly in virtue of institutional facts about money.

I use the term practice here in roughly Alasdair MacIntyre's sense. MacIntyre defines a practice as follows:

By a 'practice' I am going to mean any coherent and complex form of socially established cooperative human activity through which goods internal to that form of activity are realised in the course of trying to achieve those standards of excellence which are appropriate to, and partially definitive of, that form of activity, with the result that human powers to achieve excellence, and human conceptions of the ends and goods involved, are systematically extended. ${ }^{57}$

A practice, like an institution, is constituted partly by collective acceptance. It owes its existence to cooperative human activity. The main difference between the two concepts, however, is that a practice necessarily involves its own internal standards of excellence. Institutions, as we have seen, can play a coordinating function in enabling the collective pursuit of value. This can give people reason to engage with them. They therefore hold the potential to change the structure of the normative universe. Practices, too, can play a coordination function, but they additionally give rise to their own internal sources of value. They are perhaps best understood as specific modes of pursuing basic human values that, as MacIntyre says, systematically extend human conceptions of those values by promoting their own forms of excellence that go beyond the values themselves. ${ }^{58}$ Practices, then, can give people reasons to engage in them by providing defined and stable modes of pursuing basic values in common with other humans. However, they also create their own internal standards of excellence that participants have reason to pursue. This represents an additional way of changing the normative world.

56 See Jonathan Crowe, 'Natural Law in Jurisprudence and Politics' (2007) 27 Oxford Journal of Legal Studies 775, 788-91; Jonathan Crowe, 'Normativity, Coordination and Authority in Finnis's Philosophy of Law' in Mark Sayers and Aladin Rahemtula (eds), Jurisprudence as Practical Reason: A Celebration of the Collected Essays of John Finnis (Supreme Court Library Queensland, 2013) 95, 99-100; Jonathan Crowe and Barbora Jedličková, 'What's Wrong with Cartels?' (2016) 44 Federal Law Review 401, 40810 .

57 Alasdair MacIntyre, After Virtue - A Study in Moral Theory ( $3^{\text {rd }}$ ed, University of Notre Dame Press, 2007) 187.

58 Alasdair MacIntyre, Dependent Rational Animals - Why Human Beings Need the Virtues (Carus Publishing, 1999) 77. 
Institutions and practices, like other sources of facts and norms, play a crucial role in giving narratives their meaning. A factual or fictional narrative where the protagonist visits a bank, uses money or studies at a university relies upon the interpreter grasping the social meaning of the relevant institution. This information will be crucial in understanding the character's attitudes and motivations when, for example, she makes sacrifices in her life to join a club or send her children to school. Practices, likewise, play a fundamental and easily overlooked role in many narratives. They explain not only why a person would want to engage in a cooperative activity like chess or football, but also why it makes sense for a person engaging in that activity to acquire or practice certain specialised skills that represent excellence in the relevant domain. The reasons we have to behave in certain ways by virtue of institutions and practices are so commonplace as to seem mundane, but they are integral to the narratives we weave around our social lives.

\section{CONSTITUTIONAL NARRATIVES}

Constitutions work: they do things in the world..$^{59}$ They accomplish this, in part, by telling stories. The Australian Constitution, for example, tells a story about an 'indissoluble Federal Commonwealth' created by the people of the Australian colonies. ${ }^{60}$ The Constitution, by describing this Commonwealth, brings it into existence as both a legal entity and a feature of the social world. The Constitution also imparts information about a range of other persons and entities and prescribes norms to govern their behaviour. The persons and entities described in the Constitution do not exist merely within the pages of the document; rather, they are presumed to exist in the actual world. If they did not, then there would be no point, legally speaking, in mentioning them. In order for the Constitution to work, it needs to refer to things in the real world: a constitution that applied purely to a fictional universe would be causally inert. The lighthouses, corporations and railways featured in the Constitution are real and existing lighthouses, corporations and railways - not purely fictional, hypothetical or historical ones. Legal officials, such as judges, apply the Constitution to our interactions with these actual entities.

The Constitution, in this respect, exhibits some similarities to a factual narrative. It deals with things and events that exist in the actual world. Constitutional interpretation accordingly makes use of devices similar to those used in deciphering factual narratives. The Constitution, like many narratives, is a relatively sparse document, but we can fill in the gaps by examining how things actually are. The way things are, however, changes over time. The reference to lighthouses in section 51(vii) of the Constitution, for example, refers to those lighthouses actually present in Australia today - not the ones that existed when the provision was drafted. The reference to 'trading or financial corporations formed within the limits of the Commonwealth' in section 51(xx) refers to corporations 
recognised under state law as it applies from time to time. ${ }^{61}$ The term 'postal, telegraphic, telephonic, and other like services' in section 51(v) includes television, ${ }^{62}$ and most likely the internet, although they exceed the framers' wildest imaginings. The Constitution, in this sense, tells a story about a factual world existing outside its pages. The meaning of the Constitution shifts as this factual environment changes.

The Constitution, like factual narratives generally, relies on numerous background facts and norms that cannot be found in the text itself. It does not, however, leave these facts and norms wholly unaltered. The Constitution also institutes new entities and norms that did not exist before it was adopted. The 'indissoluble Federal Commonwealth', as we have seen, did not exist before the Constitution created it. Likewise, the Senate (section 7), House of Representatives (section 24), Governor-General (section 61) and High Court of Australia (section 71) did not exist until the Constitution brought them into being. The Constitution also confers various persons and entities with new powers and duties. In this way, it changes the factual and normative universe. The Constitution, in this respect, is not wholly analogous to a factual narrative; it also resembles a fictional narrative in the way it constructs its own factual and normative world. The Constitution neither takes the world precisely as it finds it, nor creates a new universe out of whole cloth. It therefore relies on the following kind of basic assumption:

5. The (factual and normative) world is the way it is and not some other way, except as stipulated or implied by the Constitution.

The factual context for the Constitution depends partly on social institutions and practices. Consider, for example, the prescriptions set out in Chapter II of the Constitution concerning the executive. Section 61 of the Constitution provides that the executive power of the Commonwealth is vested in the Queen and exercisable by the Governor-General. Sections 62 and 63 then provide for a Federal Executive Council to advise the Governor-General, while section 64 refers to the Ministers of State who belong to the Federal Executive Council. Various persons and entities are created and governed by these provisions. There is, however, no reference to the office of the Prime Minister - nor are any express limitations placed on the Governor-General's power to act without advice. These important features of the Australian system of government come not from the Constitution itself, but rather from longstanding practice in the United Kingdom and its colonies. ${ }^{63}$ The office of the Prime Minister is an institutional fact in Searle's sense of the term: it reflects a status function conferred upon a person who fulfils certain criteria. ${ }^{64}$

The office of the Prime Minister in the Westminster system of government is therefore established as a matter of social fact. It is no less a part of the Australian constitutional system for not being expressly delineated. The practices associated with the Westminster system generate norms of behaviour that define the roles of

61 New South Wales v Commonwealth (1990) 169 CLR 482, 502 (Mason CJ, Brennan, Dawson, Toohey, Gaudron and McHugh JJ).

62 Jones v Commonwealth [No 2] (1965) 112 CLR 206.

63 See generally Andrew Blick and George Jones, Premiership: The Development, Nature and Power of the Office of the British Prime Minister (Imprint Academic, 2010). 
both the Prime Minister and the Governor-General. It is by virtue of these salient norms and practices that the Governor-General normally should not exercise executive powers except on the advice of the Prime Minister. This context is indispensable for an accurate understanding of Chapter II of the Constitution. Social institutions perform this sort of normative function by coordinating social behaviour for the common good. Many public goods cannot be reliably secured without some degree of social coordination, although the precise way this is done may differ between communities. It is in everyone's interests to have a set of reliable, transparent standards setting out the powers and procedures applying to government officials, since this allows people to plan their lives without arbitrary interference. People therefore have reason to promote existing social institutions where they represent salient and reasonable methods of facilitating the common good. ${ }^{65}$

Constitutional narratives occur against a backdrop of social institutions. They also rely upon social practices. Constitutions exist to advance social coordination in service of the common good. Doctrines such as the rule of law, responsible government, democratic representation and the separation of powers play specific roles in pursuit of this end. They coordinate social action, while also containing their own internal standards of excellence. Government officials in a society committed to these doctrines have reason to promote the associated standards of excellence. The task of constitutional interpretation, in turn, involves engaging with the Constitution's relationship to these social norms. Chapter II of the Constitution, for example, must be interpreted by reference to not only the office of the Prime Minister, but also the standards of excellence internal to the Westminster model of responsible government. These normative standards help to explain why the Governor-General's powers should normally only be exercised on advice. Constitutional interpreters considering matters relevant to the rule of law, democratic representation or the separation of powers must likewise interpret and apply the text with regard to the current social practices giving content to those doctrines.

\section{CONSTITUTIONAL IMPLICATIONS}

The role of historically extended narratives in constitutional interpretation is far from unknown to the Australian courts, although it has rarely been explicitly discussed. There are, however, some notable exceptions. Windeyer J famously said that in the Engineers' Case, 'the Constitution was read in a new light, a light reflected from events that had, over twenty years, led to a growing realization that Australians were now one people and Australia one country and that national laws might meet national needs' ${ }^{66}$ His Honour went on to describe the significance of the case as follows: 
As I see it the Engineers' Case, looked at as an event in legal and constitutional history, was a consequence of developments that had occurred outside the law courts as well as a cause of further developments there. That is not surprising for the Constitution is not an ordinary statute: it is a fundamental law. In any country where the spirit of the common law holds sway the enunciation by courts of constitutional principles based on the interpretation of a written constitution may vary and develop in response to changing circumstances. This does not mean that courts have transgressed lawful boundaries: or that they may do so. ${ }^{67}$

Windeyer J's meaning in this passage has been disputed by commentators. ${ }^{68}$ Goldsworthy describes his view as incoherent. ${ }^{69}$ However, one possible way of understanding the passage is as capturing the indispensable role of narratives in constitutional interpretation. Changes in social institutions and practices can and should lead to changes in constitutional law, because they change the meaning of the Constitution itself. ${ }^{70}$ They change the factual and normative backdrop to the Constitution and thereby change the way it is understood by interpreters. They also change the way the Constitution works by altering its relationship to the surrounding factual and normative world.

Institutional artefacts such as the office of the Prime Minister and the doctrine of representative government form an indispensable part of the context for interpreting the Constitution. The Constitution would make little sense without them. The High Court, for its part, has recognised the role played by these institutions and social narratives in a range of different fields of constitutional jurisprudence. For example, the High Court has held that the separation of judicial power is reflected in the structure of the Constitution, giving rise to more robust protections for judicial independence than can be found in the text alone. ${ }^{71}$ The doctrine of the rule of law has been found to underpin the Constitution as a whole and to play a role in the interpretation of Commonwealth powers. ${ }^{72}$ The federal distribution of powers likewise forms the basis for the doctrine of intergovernmental immunities, despite the lack of any express provisions enshrining this protection..$^{73}$

These diverse constitutional implications - some of them disputed, others largely uncontroversial - all have their basis in a common form of reasoning. They involve looking at the constitutional provisions, discerning the functions given to them by authorial intention and social convention, then interpreting these against the wider backdrop of social institutions. The end result is that entrenched social norms and expectations concerning topics such as the separation of judicial power,

67 Ibid 396-7.

68 See, eg, H Burmester, 'Justice Windeyer and the Constitution' (1987) 17 Federal Law Review 65, 76-7; M J Detmold, 'Original Intentions and the Race Power' (1997) 8 Public Law Review 244, 250-1; Jeffrey Goldsworthy, 'Justice Windeyer on the Engineers' Case' (2009) 39 Federal Law Review 363.

69 Goldsworthy, 'Justice Windeyer on the Engineers' Case', above n 68, 373. See also Goldsworthy, 'Original Meanings and Contemporary Understandings', above n 5, 266-7.

70 See Crowe, 'The Role of Contextual Meaning', above n 12.

$71 \quad R v$ Kirby; Ex parte Boilermakers' Society of Australia (1956) 94 CLR 254, 269-70 (Dixon CJ, McTiernan, Fullagar and Kitto JJ).

72 Communist Party Case (1951) 83 CLR 1, 193 (Dixon J).

73 See, eg, Melbourne Corporation (1947) 74 CLR 31, 66 (Rich J), 70 (Starke J), 80-1, 83 (Dixon J); Clarke v Federal Commissioner of Taxation (2009) 240 CLR 272, 309 [75]-[76] (Gummow, Heydon, Kiefel and Bell JJ). 
the rule of law and the autonomy of the executive governments of the states play an integral role in how the Constitution and its provisions are understood and interpreted. The Constitution, in each of these areas, has been from time to time 'read in a new light ... [as] a consequence of developments that had occurred outside the law courts as well as a cause of further developments there'. ${ }^{74}$

The cases that established the implied constitutional freedom of political communication - Nationwide News and Australian Capital Television - provide further striking examples of the role of social narratives in grounding constitutional implications. The High Court in those cases sought to make sense of the system of representative government embodied in the Constitution. The judgments of Mason CJ and Deane, Toohey and Gaudron JJ, in so doing, clearly recognised the role of social practices and institutions in shaping the meaning and function of the constitutional provisions. Sections 7 and 24 of the Constitution, along with the other sections of the Constitution relating to the legislature, evince an intention on the part of the framers to set up a representative form of government. ${ }^{75}$ However, the content and significance of this function, as the majority judges understood, cannot be fully determined by looking at the provisions themselves.

Rather, the meaning of sections 7 and 24 -and, in particular, the sense in which they 'further the institutions of representative and responsible government' ${ }^{7}-$ depends on how those provisions interact with other social practices and institutions. It is these institutions, rather than the constitutional text alone, that provide the basis for the implied freedom and render it a part of Australian constitutional jurisprudence. Deane and Toohey JJ, for example, describe the basis of the implied freedom as follows:

Inherent in the Constitution's doctrine of representative government is an implication of the freedom of the people of the Commonwealth to communicate information, opinions and ideas about all aspects of the government of the Commonwealth, including the qualifications, conduct and performance of those entrusted ... with the exercise of any part of legislative, executive or judicial powers of government. ${ }^{77}$

The implied freedom, on this view, is not, strictly speaking, inherent in the constitutional text. Rather, it is inherent in the doctrine of representative government, which is an institutional artefact forming part of the wider narrative surrounding the Constitution. The High Court's later approach to framing the implied freedom in Lange, by contrast, obscures the role of constitutional narratives in favour of an emphasis on 'text and structure' ${ }^{78}$ This shift, as mentioned above, seems to have been intended to make the implication appear more plausible..$^{79}$ However, by disguising the role of constitutional narratives, it may well have had the opposite effect.

Payroll Tax Case (1971) 122 CLR 353, 396 (Windeyer J).

Nationwide News (1992) 177 CLR 1, 70-3 (Deane and Toohey JJ); Australian Capital Television (1992) 177 CLR 106, 137 (Mason CJ), 209-10 (Gaudron J).

Australian Capital Television (1992) 177 CLR 106, 228 (McHugh J).

Nationwide News (1992) 177 CLR 1, 74 (Deane and Toohey JJ).

(1997) 189 CLR 520, 566-7 (The Court).

But see Stone, 'The Limits of Constitutional Text and Structure', above n 8. 


\section{DEMOCRATIC MOVEMENT}

The role of contemporary social narratives in shaping (and effectively changing) the meaning of the Constitution can be clearly discerned in the High Court's reasoning in Roach. ${ }^{80}$ The majority judges in Roach decided that disqualifying all prisoners from voting in Commonwealth elections, regardless of the duration of their sentences, was a disproportionate restriction on the franchise and therefore contrary to sections 7 and 24. According to Gleeson CJ, 'the words of ss 7 and 24, because of changed historical circumstances including legislative history, have come to be a constitutional protection of the right to vote' ${ }^{81} \mathrm{His}$ Honour is quite explicit that this implied (albeit conditional) constitutional right to vote did not exist when the Constitution was first adopted. It is not a product of the constitutional text alone - although it is anchored in sections 7 and 24 - nor of the intentions of the framers. It is, rather, a result of new functions and values imposed upon those sections by surrounding constitutional narratives. This result was reached, not purely by relying on the constitutional text and structure, but by referring to the historical development of representative government as shaped by statute and social attitudes.

The role of constitutional narratives in Roach is apparent from the opening words of Chief Justice Gleeson's judgment:

The Australian Constitution was not the product of a legal and political culture, or of historical circumstances, that created expectations of extensive limitations upon legislative power for the purpose of protecting the rights of individuals. It was not the outcome of a revolution, or a struggle against oppression. It was designed to give effect to an agreement for a federal union, under the Crown, of the peoples of formerly self-governing British colonies. ${ }^{82}$

This is the beginning of the story, but not the end. The Australian Constitution was not created with rights in mind, but Australians nonetheless came to enjoy universal adult suffrage (with limited exceptions). This, as Gleeson CJ notes, 'was the result of legislative action' ${ }^{83}$ It nonetheless became a 'fact' with relevance for the meaning and application of the Constitution ${ }^{84}$ Gleeson CJ's reasoning on this point recognises the ways in which constitutional interpretation depends on facts outside the Constitution itself. The words 'foreign power' in section 41(i), he

80 The argument advanced in this article suggests that the meaning of the Constitution changes as the social environment changes. It therefore entails that the amendment procedure set out in section 128 is not the only way that the Constitution evolves over time. Section 128 nonetheless plays an important role in the Constitution, not only in providing a formal amendment process, but also as a component of the surrounding narrative about the Constitution's democratic legitimacy. This, in turn, serves as a constraining factor for judicial interpretations. For further discussion of possible constitutional amendment processes outside section 128, see Jonathan Crowe and Peta Stephenson, 'An Express Constitutional Right to Vote? The Case for Reviving Section 41' (2014) 36 Sydney Law Review 205, 226-8.

81 Roach (2007) 233 CLR 162, 174 [7]. A similar line of reasoning was applied by McTiernan and Jacobs JJ in Attorney-General (Cth) ex rel McKinlay v Commonwealth (1975) 135 CLR 1, 36. For further discussion, see Crowe and Stephenson, above n 80, 223-5. (2007) 233 CLR 162, 172 [1].

83 Ibid 173-4 [6].

84 Ibid 174 [7]. 
notes, came to include the United Kingdom by virtue of changes in 'national and international circumstances' ${ }^{85}$ The statutory recognition of universal adult suffrage is 'an historical development of constitutional significance of the same kind' ${ }^{86}$ It is because 'universal adult suffrage was a long established fact' that 'we have reached a stage in the evolution of representative government' where nothing less would satisfy the requirement in sections 7 and 24 that representatives be 'directly chosen by the people' ${ }^{87}$

What, then, is the meaning of 'directly chosen by the people' in the contemporary legal and social context? Gleeson CJ deals with this issue by recognising that, as with linguistic terms generally, there will be both easy and hard cases.$^{88}$ 'It is easy', his Honour notes, 'to multiply examples of possible forms of disenfranchisement that would be identified readily as inconsistent with choice by the people' - such as disenfranchising members of a particular religion - 'but other possible examples might be more doubtful' ${ }^{89}$ A similar point is made by Gummow, Kirby and Crennan JJ, who observe that 'a law excluding members of a major political party or residents of a particular area of a State' from the franchise would clearly be invalid, ${ }^{90}$ while other cases call for the exercise of judgment..$^{91}$ The majority judgments in Roach generally exhibit an appropriately cautious approach to dealing with borderline cases. The legislative history of disenfranchisement of prisoners in Australia, as detailed in the judgments, clearly establishes that Parliament has some leeway to disqualify serious offenders. ${ }^{92}$ However, never in Australian history has that disqualification encompassed all prisoners without distinction. It is plausible that the Australian constitutional narrative does not recognise such a measure as consistent with the practice of representative government.

This form of reasoning reflects what Gummow, Kirby and Crennan JJ call 'the evolutionary nature of representative government as a dynamic rather than purely static institution'. ${ }^{93}$ The relevant parts of the constitutional text may not change, but the institution of representative government can and does change; many of these changes, for constitutional reasons, are carried out through legislation. It is not plausible, for reasons outlined earlier in this article, to maintain that these developments have no effect on the meaning and application of the constitutional provisions. The Constitution's causal effects (through which it makes a difference to law and governance) occur in a world where representative government is a dynamic social institution. If it is true that, as McHugh $\mathrm{J}$ puts it, sections 7 and 24

85 Ibid $173-4[6]$.

86 Ibid 174 [7].

87 Ibid. Contra ibid 218-20, [157]-[162] (Hayne J).

88 This point is, of course, well known to legal theorists through its role in the work of H L A Hart. Hart famously noted that linguistic terms inevitably yield both a 'core of settled meaning' and a 'penumbra of debatable cases': H L A Hart, 'Positivism and the Separation of Law and Morals' (1958) 71 Harvard Law Review 593, 607. 
are intended to 'further the institutions of representative and responsible government', ${ }^{44}$ then their meaning cannot be discerned without enquiring into the nature of those institutions. This methodology provides the context for Justices Gummow, Kirby and Crennan's finding that 'there is long established law and custom, stemming from the terms of the institution in the Australasian colonies of representative government' whereby prisoners serving sentences for serious crimes would be disqualified from voting. ${ }^{95}$ However, it equally forms the basis for their Honours' assessment that '[t] hat tradition is broken' by a blanket ban that 'has no regard to [levels of] culpability' in imposing disqualification. ${ }^{96}$

The majority judges in Roach found that disqualifying all prisoners from voting is a disproportionate restriction on the franchise, but disqualifying only those prisoners serving sentences over three years in duration - as was required by statute from 2004 until 2006 - is not. Critics of this reasoning have depicted it as drawing an arbitrary line between proportionate and disproportionate restrictions based on recent legislative history. James Allan, for example, has accused the judges in Roach of 'Animal Farm judging', based on the maxim 'four years good ... two years bad'. ${ }^{97}$ However, this seriously mischaracterises the judges' reasoning. The majority in Roach did not draw an arbitrary line at three years; rather, the judges held that disqualifying prisoners serving sentences longer than three years was consistent with constitutional history and practice, while disqualifying all prisoners was not. The majority judgments clearly leave open the prospect that disqualifications covering prisoners serving sentences shorter than three years could be upheld; as Gleeson CJ puts it, 'I do not suggest that disenfranchisement of prisoners serving sentences of some specified lesser term would necessarily be invalid'. 98

The majority judges in Roach found that a blanket ban on prisoners voting is inconsistent with representative government. This ruling was made against the backdrop of legislative history, where prisoners serving sentences shorter than one year had been allowed to vote in Commonwealth elections ever since the Commonwealth Franchise Act 1902 (Cth). ${ }^{99}$ It was therefore based upon a social and legal practice that had persisted for more than a century. The decision to strike down the 2006 law while upholding the 2004 legislation may indeed seem arbitrary if the only reference point is the constitutional text. ${ }^{100}$ It is not arbitrary, however, if reference is made to the institutions and practices surrounding the Constitution. Representative government is an evolving institution that takes its contours from other social practices, including those created and shaped by statute and the common law. Statutory provisions can establish a baseline for social conduct by shaping community expectations about how representative government

94 Australian Capital Television (1992) 177 CLR 106, 228.

95 Roach (2007) 233 CLR 162, 200-1 [90].

96 Ibid.

97 Allan, above n 11, 750.

98 (2007) 233 CLR 162, 179-80 [19]. See also 204 [102] (Gummow, Kirby and Crennan JJ).

99 Ibid 175 [9] (Gleeson CJ).

100 The judgment of Gummow, Kirby and Crennan JJ in Roach (like the unanimous joint judgment in Lange) invites this criticism by suggesting that it is based on the 'structure and the text of the Constitution': (2007) 233 CLR 162, 187 [48]. 
and other institutions operate. The Constitution is then properly interpreted against this background context. The High Court's reasoning in Roach, viewed in this light, represents a legitimate exercise in constitutional interpretation. The judges' findings are based on a reading of the constitutional narrative; they track what might be called the democratic movement of the Australian Constitution. ${ }^{101}$

\section{CONCLUSION}

I have argued in this article that the High Court's jurisprudence on constitutional implications - at least in cases such as Nationwide News, Australian Capital Television and Roach - is not best understood as drawing Gricean implicatures or presuppositions from particular words in the Constitution. Nor does it rely on interpreting the intentions of the framers. It is, rather, an attempt to interpret the constitutional narrative by placing it in the context of the broader factual and normative universe of which it forms part. The constitutional requirement that representatives be 'directly chosen by the people' occupies a normative space alongside the social practice of representative government. The tradition surrounding that practice contains an expectation of free political speech and a universal franchise (with certain narrow exceptions). Representative government, freedom of political speech and the universal franchise form part of the Constitution in the same way that the geography of London forms part of the Holmes stories or the phenomenology of teenage obsession forms part of the Twilight universe. Constitutional interpretation involves integrating these elements into a coherent narrative.

It is for this reason that common law jurisprudence and statutory norms may be relevant to constitutional interpretation. The common law and statutes can make things normatively the case by defining the contours of institutions and practices, thereby playing a coordination role and shaping internal standards of excellence. The Constitution retains its supremacy over other legal norms, but this does not mean those norms are irrelevant to how the Constitution is interpreted. Judges may legitimately look to the common law to understand the nature and limits of constitutional entrenchment of judicial review (as in Kirk) or to statutory norms to understand the constitutional limits on legitimate restrictions on the franchise (as in Roach and Rowe). They are, in so doing, engaging with historical and current institutions and practices with a view to understanding the story the Constitution tells about the Australian system of government. Section 51(xx) tells a story about the Commonwealth Parliament and its relationship to the institution of the corporation; in the same way, sections 7 and 24 tell a story about the Houses of Parliament and their relationship to the practice of representative government. The Constitution would make little or no sense considered outside this context. ${ }^{102}$

Proponents of the intentionalist model of constitutional implications are likely to contend that the narrative model outlined in this article leads to legal

101 Crowe and Stephenson, above n 80, 223-6.

102 See Crowe, 'The Role of Contextual Meaning', above n 12. 
indeterminacy and leaves too much power in the hands of judges. ${ }^{103}$ Constitutional narratives call for interpretation; it is therefore true that they will not yield clear and determinate answers in every possible case. The existence of hard cases, of course, does not pose an insurmountable problem for the narrative model, provided that it offers the resources to reason through them and reach a defensible outcome. As Justices Gummow, Kirby and Crennan note in Roach, there is 'scope for judgment' in some cases, but the existence of grey areas 'does not deny the existence of a constitutional bedrock'. ${ }^{104}$ The appropriate methodology in such cases, I have argued, involves constructing a historically extended narrative about the social practices and institutions of which the Constitution forms part. There is nothing unusual or exotic about this approach, involving as it does a close analysis of constitutional and legislative history to discern the contextual meaning of constitutional provisions. The majority judgments in Roach provide an example of such a methodology.

The quest continues in some quarters of constitutional theory for an interpretive method that will provide sufficiently clear and precise answers as to render judges constrained in even the hardest cases. Intentionalist approaches are sometimes said by their defenders to fit this description; Allan, for example, claims that intentionalism 'lock[s] in' the constitutional settlement in a way that other theories do not. ${ }^{105}$ However, it is far from clear why working out the original intentions of the framers more than a century ago should be any easier or more determinate than working out the contextual meaning of the Constitution today. Both approaches seek to arrive at determinate meanings by interpreting historical materials. The main difference is that intentionalists must look back in time more than a hundred years to work out what the framers meant, while the narrative model focuses on understanding the Constitution's contemporary meaning, albeit within the context of a historically extended narrative. Interpretation is what judges do; it is a difficult task that sometimes leads to contestable outcomes. The task of constitutional theory is to cast light on how judges and others interpret the Constitution in a way that draws out the complexities and nuances in this area. One way that intentionalism fails is by making the task seem simpler than it is.

The narrative model, on the other hand, casts light on the High Court's complex and controversial jurisprudence on constitutional implications by showing how it relies on institutions and practices beyond the constitutional text. The Constitution works: it does things in the world. The way in which it works depends upon its causal relationships with a wide range of external institutions, ranging from banks, corporations and lighthouses to the office of the Prime Minister and representative government. The meaning and operation of the

103 See, eg, Goldsworthy, 'Constitutional Interpretation: Originalism', above n 5, 688-9.

104 (2007) 233 CLR 162, 198 [82].

105 Allan, above n 11, 762. See also Larry Alexander, 'Introduction' in Larry Alexander (ed), Constitutionalism: Philosophical Foundations (Cambridge University Press, 1998) 1; Larry Alexander, 'Simple-Minded Originalism' in Grant Huscroft and Bradley W Miller (eds), The Challenge of Originalism: Theories of Constitutional Interpretation (Cambridge University Press, 2011) 87; Richard S Kay, 'American Constitutionalism' in Larry Alexander (ed), Constitutionalism: Philosophical Foundations (Cambridge University Press, 1998) 16. 
Constitution changes as these institutions change; the High Court therefore properly makes reference to the history of these institutions - including the ways in which they are shaped by changes in statute and the common law - when interpreting and applying constitutional provisions. The Constitution, in this sense, forms part of a broader historical and social narrative; it is as part of this narrative that the constitutional text falls to be interpreted. It follows, as the majority judges in Roach recognised, that the meaning and significance of constitutional provisions is far from static. The Constitution changes as the world around it changes; in this sense, it is perpetually in movement. 